\title{
UJI EFEK ANTIBAKTERI JAMUR ENDOFIT DAUN MANGROVE AVICENNIA MARINA TERHADAP BAKTERI UJI STAPHYLOCOCCUS AUREUS DAN SHIGELLA DYSENTERIAE
}

\author{
Yolanda A. Kasi \\ Jimmy Posangi \\ P. Mona Wowor \\ Robert Bara
}

\author{
${ }^{1}$ Kandidat Skripsi Fakultas Kedokteran Universitas Sam Ratulangi Manado \\ Bagian Farmakologi dan Terapi Fakultas Kedokteran, Universitas Sam Ratulangi, Manado \\ Email : yolandakasi@gmail.com
}

\begin{abstract}
Endophytic fungi is a species of fungi which lives within plant tissues including leaf's tissues that also harmless for the host plant itself. Isolates of endophytic fungi have a potent antibacterial capability with broad spectrum. The aim of this research is to know whether there is an antibacterial effect of endophytic fungi which isolated from Avicennia marina leaf towards Staphylococcus aureus and Shigella dysenteriae. The method that is used for the antibacterial activity test, done by putting mycelia of endophytic fungi in combination media that has been smeared with Staphylococcus aureus and Shigella dysenteriae. Based on research that has been done, it obtained two types of endophytic fungi isolated from mangrove plant, Avicennia marina leaf. Both endophytic fungi have potential for inhibiting Staphylococcus aureus and Shigella dysenteriae, but endophytic fungi with white mycelium has a better antibacterial effect than endophytic fungi with black mycelium and positive control.
\end{abstract}

Keywords: antibacterial, endophytic fungi, mangrove avicennia marina

\begin{abstract}
Abstrak: Jamur endofit merupakan jamur yang hidup di dalam jaringan tanaman salah satunya yaitu dalam jaringan daun dan tidak membahayakan tanaman tersebut. Isolat-isolat jamur endofit memiliki daya antibakteri yang poten dengan spektrum luas. Penelitian ini bertujuan untuk mengetahui ada tidaknya efek antibakteri jamur endofit daun Avicennia marina terhadap bakteri Staphylococcus aureus dan Shigella dysenteriae. Metode yang digunakan untuk uji antibakteri yaitu dilakukan dengan cara menempelkan miselia jamur endofit pada media agar kombinasi yang telah dioleskan bakteri uji. Dari penelitian yang dilakukan, diperoleh dua jenis jamur endofit yang diisolasi dari daun Mangrove Avicennia marina. Kedua jamur endofit memiliki potensi dalam menghambat kedua bakteri uji tetapi jamur endofit miselium putih memiliki efek antibakteri yang lebih baik dibandingkan dengan jamur endofit miselium hitam dan kontrol positif.
\end{abstract}

Kata kunci: antibakteri, jamur endofit, daun avicennia marina

Salah satu jenis tumbuhan yang berpotensi sebagai bahan obat-obatan yaitu tumbuhan bakau atau mangrove. ${ }^{1}$ Hutan mangrove hanya terdapat di daerah ekuator hingga $23,5^{\circ} \mathrm{LU}$ dan $23,5^{\circ} \mathrm{LS}$. Tumbuhan ini berada di pantai yang rendah, tenang, berlumpur atau sedikit berpasir dan mendapat pengaruh pasang surut air laut. ${ }^{2}$

Avicennia marina merupakan salah satu spesies mangrove yang tersebar luas di Indonesia yang memiliki potensi baik sebagai bahan obat-obatan. Hampir seluruh bagian dari tanaman ini memiliki 
senyawa metabolit sekunder yang dapat dimanfaatkan dalam bidang farmakologi di antaranya alkaloid, saponin, tanin, flavonoid, triterpenoid, dan steroid. Penelitian Darminto mengungkapkan, potensi tanaman sebagai bahan obatobatan tidak hanya dari senyawa metabolit sekunder melainkan dapat juga berasal dari mikroba endofit yang hidup di dalam jaringan Avicennia sp.,

Mikroba endofit merupakan mikroba yang hidup di dalam jaringan tumbuhan dan mampu membentuk koloni dalam jaringan tumbuhan tanpa memberikan efek negatif pada inangnya. Penelitian yang dilakukan oleh Xiang Ling membuktikan bahwa dalam satu tumbuhan dapat diisolasi lebih dari satu bahkan puluhan jenis mikroba endofit yang masing-masing mempunyai potensi untuk memproduksi satu atau lebih senyawa bioaktif. ${ }^{5}$ Oleh sebab itu, penelitian-penelitian untuk mengeksplorasi keanekaragaman jenis serta kandungan zat bioaktif yang diproduksi oleh mikroba endofit tersebut perlu dilakukan.

Mikroba endofit dapat berupa bakteri, jamur atau mikroba lainnya, tetapi saat ini yang lebih banyak dieksplorasi ialah jamur-jamur endofit. Berdasarkan penelitian oleh Sinaga (2009), isolat-isolat jamur endofit memiliki daya antibakteri yang poten dengan spektrum luas. ${ }^{6}$

Staphylococcus aureus sering ditemukan sebagai bakteri flora normal pada kulit dan selaput lendir pada manusia, namun kuman ini juga dapat menjadi penyebab infeksi pada manusia maupun hewan. Staphylococcus aureus dapat menginfeksi jaringan atau alat tubuh lain yang menyebabkan timbulnya penyakit dengan tanda-tanda yang khas seperti nekrosis, peradangan dan pembentukan abses. ${ }^{7}$

Shigella dysenteriae merupakan penyebab utama disentri di Indonesia. ${ }^{8}$
Setiap tahun, diperkirakan ada sekitar 164,7 juta kasus infeksi diare yang disebabkan oleh kuman Shigella dan 163,2 juta di antaranya terjadi di negara berkembang. $^{9}$

\section{METODE PENELITIAN}

Penelitian ini dilaksanakan menggunakan metode eksperimental. Penelitian berlangsung sejak bulan September 2014 sampai Januari 2015. Penelitian dilaksanakan di Laboratorium Farmakologi dan Terapi Fakultas Kedokteran Universitas Sam Ratulangi Manado.

\section{Alat dan Bahan}

Alat-alat yang digunakan dalam penelitian ini yaitu: cawan petri, tabung reaksi, pinset, kapas lidi steril, oven, inkubator, api bunsen, jarum ose, tabung reaksi, tabung Erlenmeyer, autoclave, gunting, spidol, dan sarung tangan.

Bahan-bahan yang digunakan dalam penelitian ini yaitu: daun mangrove Avicennia marina, bakteri Staphylococcus aureus, bakteri Shigella dysenteriae, kapas steril, MEA (Malt Extract Agar), alkohol 70\%, agar plain, akuades, NA (Nutrient Agar), BHI (Brain Heart Infusion), MHA (Mueller Hinton Agar).

\section{Isolasi Jamur Endofit}

Alat-alat yang digunakan dalam penelitian ini disterilkan dalam oven pada suhu $170^{\circ} \mathrm{C}$ selama \pm 1 jam (sterilisasi kering). Media disterilkan dalam autoclave pada suhu $121^{\circ} \mathrm{C}$ selama 15 menit (sterilisasi basah). Daun mangrove jenis Avicennia marina diambil dan dibersihkan. Daun, pinset dan gunting direndam dalam larutan alkohol 70\% selama 10 detik untuk menghindari kontaminasi dari bakteri. Daun mangrove tersebut digunting membentuk persegi sebanyak 4 buah. Potongan tersebut ditanam pada media agar yang dibuat dari MEA (Malt Extract Agar) dan Agar plain di dalam cawan petri. Kloramfenikol 0,2 $\mathrm{g} / \mathrm{ml}$ sebelumnya ditambahkan ke dalam 
media agar untuk mencegah pertumbuhan bakteri lainnya. Cawan petri yang berisi daun mangrove tersebut ditutup, kemudian disimpan pada suhu kamar $\left(25^{\circ} \mathrm{C}\right)$ selama $2 \times 24$ jam untuk menumbuhkan jamur. Setelah 2x24 jam, akan terlihat pertumbuhan dari jamur di sekitar daun pada media agar. Setiap daun mangrove yang ditanam dapat menghasilkan beberapa pertumbuhan jamur endofit yang berbeda.

\section{Pemurnian Jamur Endofit}

Jamur endofit yang sudah tumbuh diambil sebagian dari miselia jamur tersebut pada permukaan agar dengan menggunakan kawat ose steril dan dipindahkan ke media MEA (Malt Extract Agar) lainnya dengan maksud untuk memurnikan pertumbuhan jamur endofit. Hal ini dilakukan pada setiap jamur endofit yang secara morfologi berbeda yang tumbuh pada daun mangrove tersebut. Pemurnian ini bertujuan untuk memisahkan koloni endofit dengan morfologi berbeda untuk dijadikan isolat tersendiri. Disimpan pada suhu ruangan selama 2x24 jam.

\section{Penyiapan Media Agar Miring dan Bakteri Uji}

Nutrient Agar (NA) ditimbang sebanyak 2,3 gram dan dilarutkan dalam $100 \mathrm{ml}$ akuades. Media kemudian disterilisasi dalam autoclave pada suhu $121^{\circ} \mathrm{C}$ selama 15 menit. Selanjutnya media dituang dalam tabung reaksi sebanyak $7 \mathrm{ml}$ dan dibiarkan mengeras dengan kemiringan $15^{\circ}$. Brain Heart Infusion (BHI) ditimbang sebanyak 3,7 gram kemudian dilarutkan dalam $100 \mathrm{ml}$ akuades. Media disterilisasi dengan autoclave pada suhu $121^{\circ} \mathrm{C}$ selama 15 menit. Media selanjutnya dituang ke tabung reaksi sebanyak $5 \mathrm{ml}$ untuk selanjutnya digunakan sebagai media suspensi bakteri. Bakteri yang dikultur pada agar miring diambil dengan kawat ose steril dan dimasukkan ke dalam media BHI. Suspensi bakteri kemudian digoreskan dengan kawat ose steril di permukaan media kombinasi. Jamur endofit yang telah tumbuh pada media MEA (Malt Extract Agar) kemudian dipotong membentuk bulat dan diletakkan pada media kombinasi MEA (Malt Extract Agar) dan MHA (Mueller Hinton Agar) yang telah digoresi bakteri uji. MHA ditimbang sebanyak 1,9 gram dan MEA ditimbang sebanyak 1,25 gram, selanjutnya dilarutkan dalam $100 \mathrm{ml}$ akuades. Media tersebut disterilisasi di autoclave dengan suhu $121^{\circ} \mathrm{C}$, kemudian tuang pada cawan petri, yang kemudian digunakan sebagai media kombinasi.

\section{Uji Kemampuan Daya Hambat Jamur Endofit dan Pengukuran Zona Hambat}

Penanaman jamur di media kombinasi MEA (Malt Extract Agar) dan MHA (Mueller Hinton Agar) dilakukan masing-masing 3 sampel jamur yang sama di 3 tempat pada 1 cawan petri. Sebagai kontrol positif diberikan larutan kloramfenikol $2 \mathrm{mg} / \mathrm{ml}$ pada kertas saring dan diletakkan di tengah-tengah media, selanjutnya diinkubasi pada suhu kamar $\left(25^{\circ} \mathrm{C}\right)$. Setelah 24 jam dengan menggunakan penggaris milimeter dilakukan pengukuran diameter zona hambat, yaitu zona bening yang terbentuk di sekitar jamur endofit dan kertas saring. Pengukuran zona hambat dilakukan menggunakan penggaris dengan cara membalik cawan petri media kombinasi dan mengukur diameter daerah jernih. Terdapat daerah jernih di sekeliling media pertumbuhan bakteri uji yang tidak ditumbuhi bakteri. Diameter zona hambat diukur dalam satuan milimeter.

\section{HASIL PENELITIAN}

Pembiakan jamur endofit yang berasal dari daun mangrove Avicennia marina menghasilkan dua jenis jamur yang kemudian dimurnikan. Secara makroskopik jamur tipe I memiliki karakteristik miselia berwarna putih sedangkan miselia jamur tipe II berwarna hitam. Diameter zona hambat yang terbentuk dari kedua jamur endofit dapat dilihat pada Gambar 1. Pengukuran 


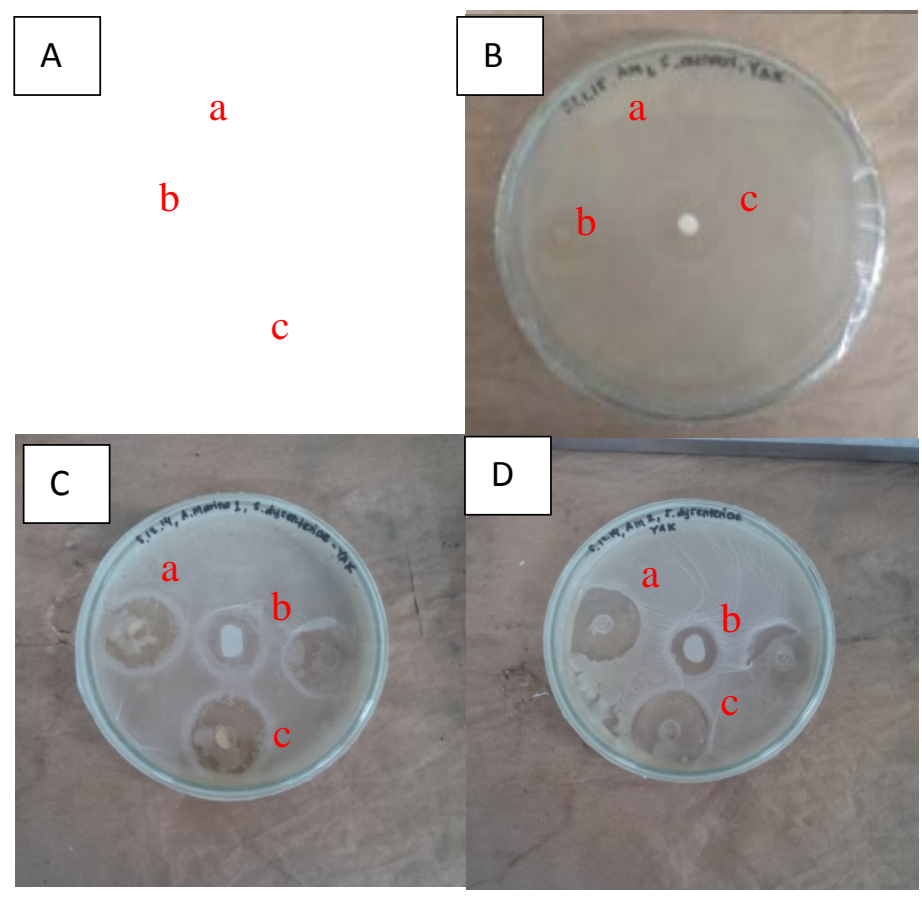

Gambar 1. A. Diameter zona hambat jamur endofit miselium putih terhadap bakteri $S$. aureus, B. Diameter zona hambat jamur endofit miselium hitam terhadap bakteri S. aureus, C. Diameter zona hambat jamur endofit miselium putih terhadap bakteri $S$. dysenteriae, D. Diameter zona hambat jamur endofit miselium hitam terhadap bakteri $S$. dysenteriae.

Tabel 1. Hasil uji efek antibakteri jamur endofit terhadap pertumbuhan bakteri Staphylococcus aureus

\begin{tabular}{ccccc}
\hline \multirow{2}{*}{ Sampel } & \multicolumn{4}{c}{ Diameter zona hambat (mm) } \\
\cline { 2 - 5 } & Jamur putih & Kontrol $(+)$ & Jamur hitam & Kontrol $(+)$ \\
\hline 1 & 20 & & 16,5 & \\
2 & 21,1 & & 17 & \\
3 & 22 & & 18 & 22 \\
Rata-Rata & 21 & 20 & 17,2 & \\
\hline
\end{tabular}

\section{BAHASAN}

Pada penelitian ini diperoleh jamur endofit miselium putih dan hitam. Kedua jenis jamur endofit tersebut diisolasi dari daun mangrove Avicennia marina. Jamur endofit yang diisolasi dilakukan pengujian daya hambat terhadap pertumbuhan bakteri uji Staphylococcus aureus dan Shigella dysenteriae. Bakteri Staphylococcus aureus sebagai bakteri Gram positif dan Shigella dysenteriae sebagai bakteri Gram negatif.
Berdasarkan hasil pengukuran setelah diinkubasi selama 24 jam, menunjukkan bahwa jamur endofit dari daun mangrove Avicennia marina menghambat pertumbuhan kedua jenis bakteri uji dengan terbentuknya zona hambat di sekitar jamur endofit. Dari hasil pengukuran diameter zona hambat, isolat jamur endofit miselium putih lebih berpotensi terhadap bakteri Gram positif dibandingkan Gram negatif. 
Tabel 2 : Hasil uji efek antibakteri jamur endofit terhadap pertumbuhan bakteri Shigella dysenteriae

\begin{tabular}{ccccc}
\hline \multirow{2}{*}{ Sampel } & \multicolumn{4}{c}{ Diameter zona hambat (mm) } \\
\cline { 2 - 5 } & Jamur putih & Kontrol (+) & Jamur hitam & Kontrol (+) \\
\hline 1 & 26,4 & & 29 & \\
2 & 27,2 & & 27,2 & \\
3 & 27,4 & & 28,4 & \\
Rata-Rata & 27 & 18 & 28,2 & 20,3 \\
\hline
\end{tabular}

Pengamatan pada isolat jamur endofit miselium hitam memberikan hasil yang berbeda, yaitu lebih berpotensi terhadap bakteri Gram negatif dibandingkan dengan bakteri Gram positif.

Isolat jamur endofit miselium putih juga memiliki aktivitas daya hambat yang lebih besar dibandingkan kontrol positif. Hal ini mungkin dapat terjadi karena beberapa hal, seperti konsentrasi jamur endofit lebih besar dibandingkan konsentrasi kontrol positif yang diberikan, pengolesan bakteri kurang merata dan mungkin karena senyawa aktif yang dihasilkan jamur endofit lebih efektif dibandingkan kontrol positif.

Pada jamur endofit miselium putih dan hitam diduga terdapat senyawa antibakteri, dugaan ini diperkuat dengan ditemukannya senyawa cytocidal, chlovalicin, isocoumarins, dan senyawa taxol yang berfungsi sebagai antibiotik, anti inflamasi, anti alergi dan anti kanker. Senyawa cytocidal dan chlovalicin ditemukan dalam jamur endofit yang diisolasi dari tumbuhan bakau Kandelia candel. Senyawa isocoumarins ditemukan dalam jamur endofit yang diisolasi dari daun muda tumbuhan mangrove Avicennia marina yang ditemukan di Pearl River Estuary, Cina Selatan dan senyawa taxol diisolasi dari jamur endofit Taxomyces andreanae yang tumbuh pada tumbuhan Taxus pasifica. ${ }^{28,29,30}$

Hasil dari penelitian ini menunjukkan bahwa jamur endofit yang diisolasi dari tumbuhan mangrove
Avicennia marina memiliki efek antibakteri terhadap kedua jenis bakteri uji di mana Staphylococcus aureus mewakili bakteri Gram positif dan bakteri Gram negatif diwakili oleh Shigella dysenteriae, maka dapat disimpulkan bahwa jamur endofit yang diisolasi dari daun mangrove Avicennia marina memiliki aktivitas penghambatan terhadap pertumbuhan bakteri uji Staphylococcus aureus dan Shigella dysenteriae.

\section{SIMPULAN}

Berdasarkan hasil pengujian jamur endofit, dapat disimpulkan bahwa jamur endofit yang diisiolasi dari daun Mangrove jenis Avicennia marina memiliki efek antibakteri terhadap pertumbuhan kedua jenis bakteri uji, yaitu Staphylococcus aureus dan Shigella dysenteriae.

\section{SARAN}

Perlu dilakukan penelitian lebih lanjut untuk mengidentifikasi senyawa yang berkhasiat anti pertumbuhan bakteri pada jamur endofit yang diisolasi dari tumbuhan Mangrove Avicennia marina, mekanisme kerja anti pertumbuhan bakteri pada jamur endofit daun Mangrove Avicennia marina dan perlu penelitian lebih lanjut tentang kemampuan daya hambat pertumbuhan bakteri menggunakan jamur endofit yang diisolasi dari bagian lain tumbuhan Mangrove Avicennia marina. 


\section{DAFTAR PUSTAKA}

1. Mulyadi E, Hendriyanto O dan Fitriani N. Konservasi hutan mangrove sebagai ekowisata. Jurnal Ilmiah Teknik Lingkungan. 2009;1:51-8.

2. Arief A. Hutan dan kehutanan. Yogyakarta: KANISIUS; 2001.42.

3. Darminto, Ali A dan Dini I. Identifikasi senyawa metabolit sekunder potensial mengahambat pertumbuhan bakteri Aeromonas hydrophyla dari kulit batang tumbuhan Avicennia spp. Jurnal Chemica. 2009;10(2):92-9.

4. Avicennia marina. [diambil 29 Sep 2014]. Dikutip dari http://media.unpad.ac.id/thesis/230210/ 2009/230210090012_2_1681.pdf

5. Xiang L, Lu C, Huang Y, Zeng Z, Su W and Shen $\mathbf{Y}$. Endophytic fungi from a pharmaceutical plant, Camptotheca acuminata: isolation, identification and bioactivity.
World Journal of Microbiology and Biotechnology. 2007;23(7):1037-040.

6. Sinaga E, Noverita dan Fitria D. Daya antibakteri jamur endofit yang diisolasi dair daun dan rimpang lengkuas (Alpinia galangal Sw.). Jurnal Farmasi Indonesia. 2009;4(4):161-70.

7. Aulia A, Thihana dan Mirhanuddin. Potensi ekstrak kayu ulin (eusideroxylon zwageri $\mathrm{T}$ et $\mathrm{B}$ ) dalam menghambat pertumbuhan bakteri Staphylococcus aureus secara in vitro. Bioscientiae. 2007;4(1):37-42.

8. Victoria CG, Bryce J, Fantaine $O$ and Memasch R. Reducing deaths from through oral rehydration therapy. Bull World Health Organ 2000;78:1246-55.

9. Kosek M, Bern C and Guerrant RI. The global burden of diarrheal disease, as estimated from studies published between 1992-2000. Bull World Health Organ 2003;81:197-204. 